\title{
Psychosocial care in the Department of Pediatric Hematology and Oncology of public hospitals in Argentina
}

\author{
Débora Farberman, B.S. ${ }^{a}$, Teresa Méndez, B.S. ${ }^{b}$, Leticia García, B.S. ${ }^{b}$, Lucía Salvia, M.D. ${ }^{a}$ \\ and Silvia Otarola, B.S. ${ }^{c}$
}

\begin{abstract}
Background. Blood diseases and cancer are part of a group of rare conditions in pediatrics. In general, cancer treatments are prolonged (months or years), so psychosocial support has been introduced to provide comprehensive care to these patients.

Objective:Toexplore psychosocial care provided at the public hospitals of Argentina to children and adolescents with cancer.

Population and Methods. An electronic questionnaire was sent to the heads of the Departments of Hematology and Oncology, Mental Health, and Social Services of 27 public hospitals providing care to pediatric patients with cancer. The survey included questions related to psychosocial care provided to this group of patients. Answers were collected and processed in the 2013-2014 period.
\end{abstract}

Results. Of the total number of health care providers contacted, $62.6 \%(47 / 75)$ completed the questionnaire. As per hematologistoncologists, the three specialties complied with Society of Pediatric Oncology to a greater extent than that reported by the psychosocial area. Such difference was repeatedly observed in all answers. The standards that were observed more consistently were continuation of education and care of healthy siblings. The health care providers from the three specialties indicated that they lacked formal mechanisms to detect failures in treatment adherence in an early manner, although treatment withdrawal interventions were systematized. Providers from the psychosocial area indicated that human resources were lacking and perceived little interdisciplinary work.

Conclusions. This study reported partial adherence to the standards recommended by the International Society of Pediatric Oncology. The assessment made by hematologists-oncologists was different from that made by health care providers from the psychosocial area.

Key words: psychosocial care, hematology, oncology, pediatrics, public hospitals.

http://dx.doi.org/10.5546/aap.2017.eng.110

E-mail address:

Débora Farberman, B.S.: deborafar@hotmail.com

Funding:

None.

Conflict of interest:

None.

Received: 5-10-2016 Accepted: 9-26-2016

To cite: Farberman D, Méndez T, García L, et al. Psychosocial care in the Department of Pediatric Hematology and Oncology of public hospitals in Argentina. Arch Argent Pediatr 2017;115(2):110-117.

\section{Collaborators:} the recommendations made by the International

\section{INTRODUCTION}

Blood diseases and cancer are rare during childhood. Their annual incidence is estimated at 12-14 children per every 100000 children younger than 15 years old. ${ }^{1}$ Each year in Argentina, approximately 1272 new cases are diagnosed; of these, $75 \%$ are treated in public hospitals. In Argentina, it has been reported that the chances of survival at 3 years of diagnosis are $61.7 \% .^{2}$ Cancer treatments are prolonged. Patients suffer different physical and emotional symptoms that affect their quality of life and that of their families. An inadequate management of emotional distress is a predictor of a greater use of health resources, in turn resulting in increased medical costs. ${ }^{3}$ In this setting, psychosocial support has been introduced to provide patients with comprehensive care.

The International Society of Pediatric Oncology (Société Internationale d'Oncologie Pédiatrique, SIOP) in 1991 constituted the Committee on Psychosocial Issues, which drafted the recommendations for psychosocial care to patients and their families. ${ }^{4}$

More recently, another group of experts ${ }^{5}$ developed care standards related to 15 psychosocial topics, ${ }^{6}$ mostly consistent with those proposed by the SIOP.

In early 2012, and based on an invitation submitted by the Argentine Society of Pediatric Hematology and

Magdalena Capurro, B.S. ${ }^{b}$, Nora Souza, B.S. ${ }^{c}$, Mariana Moser, B.S. ${ }^{d}$, Josefina Carro, B.S. ${ }^{e}$, Verónica Santos, B.S. ${ }^{f}$, Susana Quintana, B.S. ${ }^{c}$ and Edith Gryinszpancholck ${ }^{b}$ 
Oncology (Sociedad Argentina de Hematooncología Pediátrica, SAHOP), a group of health care providers who worked in hospitals where children with cancer were treated established a group targeted at developing a psychosocial care network inside the public health system and conducting joint investigations. This study is the result of that initiative.

Objective: To explore psychosocial care provided at public hospitals in Argentina to pediatric patients with cancer based on the SIOP recommendations.

\section{POPULATION AND METHODS}

This was a descriptive, multicenter study conducted between March 2013 and August 2014. Data were collected using a questionnaire made up of 52 questions, mostly close-ended, targeted at gathering information (facts and opinions) about the care provided regarding the 11 recommendations made by the SIOP (see Annex).

The questionnaire was developed by psychosocial care actors using the SurveyMonkey tool. Questions were organized into areas based on the SIOP recommendations: a) information/ communication; $b$ ) therapeutic alliance; $c$ ) informed consent and decision-making; d) rejection, noncompliance, and treatment withdrawal; e) education; f) sibling care; g) nonconventional therapies; h) survivors; i) terminally ill patients; j) burnout; k) psychosocial staff availability. Knowledge on the SIOP recommendations was investigated.
Hematologists-oncologists, psychologists / psychiatrists, and social workers were considered key informants. To this end, we contacted the heads of these departments from 27 out of the 28 public hospitals treating children and adolescents with cancer in Argentina (Table 1). The questionnaire was inadvertently sent to health care providers of Hospital Dr. H. Notti from Mendoza. The survey was described to participants on the telephone; they were asked to answer reflecting the opinion of their department staff working with patients with blood diseases and cancer. The questionnaire was sent, and three reminders were made to request participants to complete the survey in the following 5 months.

In some hospitals, answers were provided separately by the heads of the Hematology and Oncology Departments because of their functioning structure. Both questionnaires were included in the final analysis. Some hospitals reported that there was no head in the Social Services area or no staff working in Childhood and Adolescence Mental Health. Some health care providers were left out because their contact information was not available.

The questionnaire was sent to 28 heads of the Department of Hematology and/or Oncology, 21 heads of the Department of Mental Health, and 26 heads of the Department of Social Services.

\section{RESULTS}

Out of the 75 health care providers contacted, $62.6 \%(47 / 75)$ completed the questionnaire: $42.5 \%$ (20/47) were hematologists-oncologists; $25.5 \%$

TABLE 1. Hospitals participating in the study

\begin{tabular}{|c|c|c|c|}
\hline Province & Hospital & Province & Hospital \\
\hline Buenos Aires & De Niños "Sor M. Ludovica" (La Plata) & Entre Ríos & De Niños San Roque \\
\hline \multicolumn{2}{|c|}{ Materno Infantil (San Isidro) } & Formosa & Hospital de la Madre y el Niño \\
\hline \multicolumn{2}{|c|}{ Nacional "Prof. Alejandro Posadas" } & Jujuy & De Niños “Dr. H. Quintana” \\
\hline \multicolumn{2}{|c|}{ Materno Infantil (Mar del Plata) } & Misiones & Provincial de Pediatría \\
\hline \multicolumn{2}{|c|}{ Interzonal “Dr. J. Penna” (Bahía Blanca) } & Neuquén & Provincial "Dr. Castro Rendón" \\
\hline \multicolumn{4}{|l|}{ Autonomous City of } \\
\hline Buenos Aires (CABA) & De Pediatría SAMIC “Prof. Dr. J. P. Garrahan” & Salta & Nuevo Htal. Materno Infantil de Salta \\
\hline \multicolumn{2}{|c|}{ General de Niños “Dr. Ricardo Gutiérrez" } & San Juan & De Niños "Juan Carlos Navarro" \\
\hline \multicolumn{2}{|c|}{ De Pediatría "Pedro de Elizalde" } & Santa Fe & De Niños “V. J. Vilela” \\
\hline \multicolumn{2}{|c|}{ De Clínicas “José de San Martín" } & & De Niños "Dr. Orlando Alassia" \\
\hline Catamarca & Interzonal de Niños "Eva Perón" & & Hospital “J. B. Iturraspe" \\
\hline Córdoba & De Niños de la Santísima Trinidad & & Provincial del Centenario (Rosario) \\
\hline Infantil Municipal & Santiago del Estero & \multicolumn{2}{|c|}{ Hospital de Niños "Eva Perón" } \\
\hline Corrientes & Pediátrico “J. Pablo II" & \multirow[t]{2}{*}{ Tucumán } & Del Niño Jesús \\
\hline Chaco & Pediátrico "Dr. A. L. Castelán” & & \\
\hline
\end{tabular}


$(12 / 47)$ worked in the Department of Mental Health; and 32\% (15/47), in the Department of Social Services. Out of all hematologistsoncologists, all Mental Health providers, and all Social Services workers, $71.4 \%$ (20/28), 57.14\% $(12 / 21)$; and $60 \%(15 / 25)$, respectively, completed the questionnaire. Data were collected from $92.59 \%$ of all contacted hospitals (25/27).

\section{Human resources}

Among the Departments of Mental Health and Social Services, $75 \%$ and $60 \%$ of participants considered, respectively, that their human resources were not enough to provide care to patients with blood diseases and cancer. This was also perceived by half of all hematologistsoncologists (Table 2).

Most (94\%) of those who indicated that psychosocial human resources were enough received help from organizations outside the hospital that provided psychological care to patients.

Also, $95 \%, 75 \%$, and $73 \%$ of health care providers from the Departments of Hematology and Oncology, Mental Health, and Social Services, respectively, reported that there were contract employees to care for these patients.

No specific provider was contracted to care for patients with cancer according to $50 \%$ of replies from the Department of Mental Health, and 33.3\% from the Department of Social Services: any psychologist/social worker available at the time responded to requests at random.

As per replies, $83 \%$ of health care providers from the Department of Mental Health and 93\% from the Department of Social Services caring for patients with blood diseases and cancer were not exclusively dedicated to working with these patients; instead, they responded to requests made by any of the hospital departments.

\section{Information-communication}

Medical information shared with patients and their families was mainly managed by hematologists-oncologists. The health care providers from the Departments of Mental Health and Social Services participated in diagnosis communication and general medical information sharing to a lesser extent: $33 \%$ and $20 \%$, respectively.

TABLE 2. Questions regarding human resources

\begin{tabular}{|c|c|c|c|}
\hline Human resources & $\begin{array}{l}\text { Hematology } \\
\text { and Oncology } \\
\qquad N=20\end{array}$ & $\begin{array}{c}\text { Mental } \\
\text { Health } \\
\mathrm{N}=12\end{array}$ & $\begin{array}{c}\text { Social } \\
\text { Services } \\
\mathrm{N}=15\end{array}$ \\
\hline $\begin{array}{l}\text { Is the staff that provides care to patients with blood diseases } \\
\text { and cancer SUFFICIENT? }\end{array}$ & $10(50 \%)$ & $2(17 \%)$ & $2(13 \%)$ \\
\hline $\begin{array}{l}\text { Is the staff that provides care to patients with blood diseases } \\
\text { and cancer INSUFFICIENT? }\end{array}$ & $10(50 \%)$ & $9(75 \%)$ & $9(60 \%)$ \\
\hline Does not answer. & 0 & $1(8 \%)$ & $4(27 \%)$ \\
\hline $\begin{array}{l}\text { Are the staff members who provide care to patients with blood diseases } \\
\text { and cancer contract employees? }\end{array}$ & $19(95 \%)$ & $9(75 \%)$ & $11(73 \%)$ \\
\hline $\begin{array}{l}\text { Are the staff members who provide care to patients with blood diseases } \\
\text { and cancer NOT contract employees? }\end{array}$ & $1(5 \%)$ & $2(15 \%)$ & $1(7 \%)$ \\
\hline Does not answer. & 0 & $1(10 \%)$ & $3(20 \%)$ \\
\hline $\begin{array}{l}\text { Do you have psychologists/psychiatrists specifically dedicated to working } \\
\text { with patients with blood diseases and cancer (always and often) } ?^{1}\end{array}$ & & $7(50 \%)$ & \\
\hline $\begin{array}{l}\text { Do you have psychologists/psychiatrists specifically dedicated to working } \\
\text { with patients with blood diseases and cancer (never and sometimes)? }\end{array}$ & & $4(33 \%)$ & \\
\hline Does not answer. & & $1(8 \%)$ & \\
\hline $\begin{array}{l}\text { Do you have social workers specifically dedicated to working with patients } \\
\text { with blood diseases and cancer (always and often)? }\end{array}$ & & & $5(33.3 \%)$ \\
\hline $\begin{array}{l}\text { Do you have social workers specifically dedicated to working with patients } \\
\text { with blood diseases and cancer (never and sometimes)? }\end{array}$ & & & $5(33.3 \%)$ \\
\hline Does not answer. & & & $5(33.3 \%)$ \\
\hline $\begin{array}{l}\text { Do you receive help from foundations or organizations outside the hospital } \\
\text { that provide care to patients with blood diseases and cancer (always or often)? }\end{array}$ & $15(75 \%)$ & $6(50 \%)$ & $9(60 \%)$ \\
\hline $\begin{array}{l}\text { Do you receive help from foundations or organizations outside the hospital } \\
\text { that provide care to patients with blood diseases and cancer (never or sometimes)? }\end{array}$ & $3(15 \%)$ & $5(42 \%)$ & 0 \\
\hline Does not answer. & $2(10 \%)$ & $1(8 \%)$ & $6(40 \%)$ \\
\hline
\end{tabular}

${ }_{1}^{1}$ Answers regarding mental health provided by the Department of Mental Health.

${ }^{2}$ Answers regarding social services provided by the Department of Social Services. 
Other communication-related topics (encouraging family talk, dispelling doubts, seeking guidance, and actively participating in decision-making) were very frequently taken into consideration by hematologists-oncologists and providers from the Department of Mental Health (95\% and $92 \%)$, and less frequently by workers from the Department of Social Services (33\%).

Also, 85\% of hematologists-oncologists and $75 \%$ of providers from the Department of Mental Health considered that, at their hospital, the informed consent was obtained with sufficient data and time to make a thoughtful and conscious decision. This percentage decreased to 53\% among providers from the Department of Social Services (Table 3).

\section{Dropout and treatment withdrawal}

A systematic intervention strategy for treatment withdrawals or negligent care was described by $90 \%$ of hematologists-oncologists, $59 \%$ of providers from the Department of Mental Health, and $66 \%$ of social workers. The early detection of noncompliance was less systematic: $65 \%$ of hematologists-oncologists, $50 \%$ of providers from the Department of Mental Health, and $46.6 \%$ of workers from the Department of Social Services indicated that their hospital had formal mechanisms in place for an early detection (Table 4).

\section{Education}

Ninety percent of health care providers indicated that their hospital had a hospital

TABLE 3. Questions regarding information-communication

\begin{tabular}{|c|c|c|c|}
\hline Information-communication & $\begin{array}{l}\text { Hematology } \\
\text { and Oncology } \\
\qquad=20\end{array}$ & $\begin{array}{c}\text { Mental } \\
\text { Health } \\
\mathrm{N}=12\end{array}$ & $\begin{array}{c}\text { Social } \\
\text { Services } \\
N=15\end{array}$ \\
\hline $\begin{array}{l}\text { At your department, do health care providers provide } \\
\text { diagnosis information to parents (always or often)? }\end{array}$ & $18(90 \%)$ & $4(33 \%)$ & $3(20 \%)$ \\
\hline $\begin{array}{l}\text { At your department, do health care providers provide } \\
\text { diagnosis information to parents (never or sometimes)? }\end{array}$ & $2(10 \%)$ & $7(59 \%)$ & $11(73 \%)$ \\
\hline Does not answer. & 0 & $1(8 \%)$ & $1(7 \%)$ \\
\hline $\begin{array}{l}\text { Is there an interdisciplinary agreement on how to provide information } \\
\text { to patients (always or often)? }\end{array}$ & $17(85 \%)$ & $7(58 \%)$ & $5(33 \%)$ \\
\hline $\begin{array}{l}\text { Is there an interdisciplinary agreement on how to provide information } \\
\text { to patients (never or sometimes)? }\end{array}$ & $3(15 \%)$ & $4(34 \%)$ & $7(47 \%)$ \\
\hline Does not answer. & 0 & $1(8 \%)$ & $3(20 \%)$ \\
\hline $\begin{array}{l}\text { At your department, do health care providers encourage intra-family } \\
\text { communication with patients and their families (always or often)? }\end{array}$ & $19(95 \%)$ & $11(92 \%)$ & $5(33 \%)$ \\
\hline $\begin{array}{l}\text { At your department, do health care providers encourage intra-family } \\
\text { communication with patients and their families (never or sometimes)? }\end{array}$ & 0 & 0 & $7(47 \%)$ \\
\hline Does not answer. & $1(5 \%)$ & $1(8 \%)$ & $3(20 \%)$ \\
\hline
\end{tabular}

TABLE 4. Questions regarding dropout and treatment withdrawal

\begin{tabular}{lccc}
\hline Dropout and treatment withdrawal & $\begin{array}{c}\text { Hematology } \\
\text { and Oncology } \\
\mathbf{N = 2 0}\end{array}$ & $\begin{array}{c}\text { Mental } \\
\text { Health } \\
\mathbf{N = 1 2}\end{array}$ & $\begin{array}{c}\text { Social } \\
\text { Services } \\
\mathbf{N = 1 5}\end{array}$ \\
\hline $\begin{array}{l}\text { ¿Utilizan mecanismos formales para detectar tempranamente el } \\
\text { abandono de tratamiento (siempre o a menudo)? }\end{array}$ & $13(65 \%)$ & $6(50 \%)$ & $7(46,6 \%)$ \\
$\begin{array}{l}\text { Do you have formal mechanisms in place to detect treatment } \\
\text { withdrawals in an early manner (always or often)? }\end{array}$ & $13(65 \%)$ & $6(50 \%)$ & $7(46.6 \%)$ \\
$\begin{array}{l}\text { Do you have formal mechanisms in place to detect treatment } \\
\text { withdrawals in an early manner (never or sometimes)? }\end{array}$ & $6(30 \%)$ & $5(41 \%)$ & $4(26.6 \%)$ \\
$\begin{array}{l}\text { Does not answer. } \\
\begin{array}{l}\text { Do you act in a systematic manner in the case of treatment } \\
\text { withdrawal or negligent care (always or often)? }\end{array}\end{array}$ & $1(5 \%)$ & $1(8 \%)$ & $4(26.6 \%)$ \\
$\begin{array}{l}\text { Do you act in a systematic manner in the case of treatment } \\
\text { withdrawal or negligent care (never or sometimes)? }\end{array}$ & $18(90 \%)$ & $7(59 \%)$ & $10(66 \%)$ \\
\begin{tabular}{l} 
Does not answer. \\
\hline
\end{tabular} & $1(5 \%)$ & $4(33 \%)$ & $1(7 \%)$ \\
\end{tabular}


school; and a high percentage of hematologists and providers from the Department of Mental Health $(95 \%$ and $84 \%)$ referred that, together with families, they encouraged patients to continue their education during and after treatment. Hematologists-oncologists described a greater contact with schools.

\section{Sibling care}

Among hematologists-oncologists and providers from the Department of Mental Health, $75 \%$ indicated that they talked to parents about the importance of taking care of the patient's siblings; this was also mentioned by $60 \%$ of social workers.

\section{Nonconventional therapies}

Half of health care providers from the psychosocial area indicated that they were not aware of the differences between complementary therapies and alternative therapies. However, hematologists-oncologists stated that they had a greater knowledge about this topic (85\%), but only half of them discussed it with the patient's family.

\section{Follow-up of surviving patients}

Among hematologists-oncologists, $80 \%$ stated that they provided systematic follow-up of patients once they completed treatment. The percentage was smaller among the providers of the Departments of Mental Health (58\%) and Social Services (20\%).

\section{Palliative care}

Approximately $60 \%$ of hematologistsoncologists and providers of the Department of Mental Health indicated that palliative care providers were requested to see patients during treatment. The percentage was smaller among workers from Social Services (46\%).

\section{Patients with incurable disease}

Among hematologists-oncologists, $85 \%$ stated that the decision to discontinue curative treatment and provide palliative care to an incurable patient was made by a group of health care providers and/or specialists. Only 50\% of the heads of the Department of Mental Health and $46 \%$ of the Department of Social Services shared this opinion.

TABLE 5. Questions regarding patients with incurable disease

\begin{tabular}{|c|c|c|c|}
\hline Patient with incurable disease & $\begin{array}{c}\text { Hematology } \\
\text { and Oncology } \\
\mathrm{N}=20\end{array}$ & $\begin{array}{c}\text { Mental } \\
\text { Health } \\
\mathrm{N}=12\end{array}$ & $\begin{array}{c}\text { Social } \\
\text { Services } \\
\mathrm{N}=15\end{array}$ \\
\hline $\begin{array}{l}\text { Is the decision to discontinue a curative treatment made by a group } \\
\text { of health care providers (always or often)? }\end{array}$ & $17(85 \%)$ & $6(50 \%)$ & $7(46 \%)$ \\
\hline $\begin{array}{l}\text { Is the decision to discontinue a curative treatment made by a group } \\
\text { of health care providers (never or sometimes)? }\end{array}$ & $1(5 \%)$ & $4(33 \%)$ & $2(14 \%)$ \\
\hline Does not answer. & $2(10 \%)$ & $2(17 \%)$ & $6(40 \%)$ \\
\hline $\begin{array}{l}\text { Is the decision to discontinue a curative treatment made together } \\
\text { with the family (always or often)? }\end{array}$ & $18(90 \%)$ & $8(67 \%)$ & $7(46 \%)$ \\
\hline $\begin{array}{l}\text { Is the decision to discontinue a curative treatment made together } \\
\text { with the family (never or sometimes)? }\end{array}$ & 0 & $1(8 \%)$ & $1(7 \%)$ \\
\hline Does not answer. & $2(10 \%)$ & $3(25 \%)$ & $7(47 \%)$ \\
\hline $\begin{array}{l}\text { Is the decision to discontinue a curative treatment made together } \\
\text { with the patient (always or often)? }\end{array}$ & $9(45 \%)$ & $3(25 \%)$ & $4(26 \%)$ \\
\hline $\begin{array}{l}\text { Is the decision to discontinue a curative treatment made together } \\
\text { with the patient (never or sometimes)? }\end{array}$ & $10(50 \%)$ & $7(58 \%)$ & $4(27 \%)$ \\
\hline Does not answer. & $1(5 \%)$ & $2(17 \%)$ & $7(47 \%)$ \\
\hline $\begin{array}{l}\text { At your department, do you consider the risk of therapeutic obstinacy } \\
\text { (always or often)? }\end{array}$ & $16(80 \%)$ & $7(59 \%)$ & $6(40 \%)$ \\
\hline $\begin{array}{l}\text { At your department, do you consider the risk of therapeutic obstinacy } \\
\text { (never or sometimes)? }\end{array}$ & $2(10 \%)$ & $3(25 \%)$ & $2(13 \%)$ \\
\hline Does not answer. & $2(10 \%)$ & $2(16 \%)$ & $7(47 \%)$ \\
\hline $\begin{array}{l}\text { At your department, do you offer further visits for bereaved families } \\
\text { (always or often)? }\end{array}$ & $15(75 \%)$ & $6(50 \%)$ & $8(53 \%)$ \\
\hline $\begin{array}{l}\text { At your department, do you offer further visits for bereaved families } \\
\text { (never or sometimes)? }\end{array}$ & $4(20 \%)$ & $5(42 \%)$ & $3(20 \%)$ \\
\hline Does not answer. & $1(5 \%)$ & $1(8 \%)$ & $4(27 \%)$ \\
\hline
\end{tabular}


Answers reflected that this type of decision was made together with parents much more often than with patient participation (Table 5).

\section{Burnout}

As shown in Table 6, hematologists-oncologists indicated that they perceived a more positive work environment than health care providers from the Departments of Mental Health and Social Services.

\section{Access to psychosocial care}

Among hematologists-oncologists, 90\% stated that they always or often requested the intervention of the Department of Mental Health, and $95 \%$ indicated that they did so with the Department of Social Services.

Between $70 \%$ and $80 \%$ of hospitals reported that patients may receive psychosocial care immediately or at a later time if they requested it on their own at the same department.

Only $55 \%$ of hematologists-oncologists were aware that there were free brochures available for patients.

\section{DISCUSSION}

The results of this study show partial adherence to the SIOP recommendations on psychosocial care provided at the public hospitals of Argentina. There is a big difference in the perception of psychosocial care providers and that of hematologists-oncologists, who consider that all services comply with standards to a greater extent. It is unknown whether such differences could be explained by different assessment parameters used in the medical and the psychosocial care practice, or because some of the assessed standards are implemented in the setting of medical interventions (such as providing diagnosis information or obtaining an informed consent), or are the result of little integration among the departments, thus generating a difference in the assessment and implementation of the SIOP standards.

Other studies ${ }^{7}$ have reported deficiencies in the integration of psychosocial care into cancer treatment protocols, although it is known that this disease poses a major emotional and social challenge to patients.

Specific psychosocial care actions, such as emotional support or family strengthening, usually led by psychologists / psychiatrists and social workers, were not explored in this study because they are not included in the SIOP recommendations.

In relation to the question about whether the different departments make decisions and develop strategies together, hematologistsoncologists showed a high frequency of teamwork whereas providers from the Departments of Mental Health and Social Services admitted that their interdisciplinary work was rather limited. The situation is similar in relation to the information provided to patients: the Department of Hematology and Oncology reported they had interdisciplinary protocols in place to provide information unknown to the Departments of Mental Health and Social Services.

As per results, it is necessary to increase interdisciplinary work, not only in relation to patient care, but also within health care teams, to strengthen existing interdisciplinary groups, train health care providers in an integrating perspective, provide specific training, enable exchange, and agree upon institutional intervention strategies.

According to the Argentine Hospital Oncopediatric Registry (Registro Oncopediátrico

TABLE 6. Questions regarding burnout

\begin{tabular}{|c|c|c|c|}
\hline Burn-out & $\begin{array}{l}\text { Hematology } \\
\text { and Oncology } \\
\qquad N=20\end{array}$ & $\begin{array}{c}\text { Mental } \\
\text { Health } \\
\mathrm{N}=12 \\
\end{array}$ & $\begin{array}{c}\text { Social } \\
\text { Services } \\
\mathrm{N}=15\end{array}$ \\
\hline $\begin{array}{l}\text { At your department, do you have a "safe" place where you can share } \\
\text { your opinions and doubts (always or often)? }\end{array}$ & $14(70 \%)$ & $6(50 \%)$ & $7(46 \%)$ \\
\hline $\begin{array}{l}\text { At your department, do you have a "safe" place where you can share } \\
\text { your opinions and doubts (never or sometimes)? }\end{array}$ & $5(25 \%)$ & $5(42 \%)$ & $4(27 \%)$ \\
\hline Does not answer. & $1(5 \%)$ & $1(8 \%)$ & $4(27 \%)$ \\
\hline $\begin{array}{l}\text { At your department, do health care providers work in an environment } \\
\text { of mutual support, trust, and learning (always or often)? }\end{array}$ & $19(95 \%)$ & $7(59 \%)$ & $8(53 \%)$ \\
\hline $\begin{array}{l}\text { At your department, do health care providers work in an environment } \\
\text { of mutual support, trust, and learning (never or sometimes)? }\end{array}$ & 0 & $4(33 \%)$ & $3(20 \%)$ \\
\hline Does not answer. & $1(5 \%)$ & $1(8 \%)$ & $4(27 \%)$ \\
\hline
\end{tabular}


Hospitalario Argentino, ROHA), all Argentine hospitals that provide care to pediatric cancer patients, except two, offer the services of a "pediatric psychologists specialized in cancer." ${ }^{2}$ However, this study indicates that this is not reliable information because the availability of psychologists is not consistent with the availability of providers specifically trained to manage cancer: only 7 hospitals have health care providers specifically devoted to this population; in the remaining hospitals, referrals are randomly made to any psychologist, probably one who is not acquainted with the specific problems of patients with blood diseases and cancer.

It is worth noting that health care providers who systematically see patients with a common problem become more knowledgeable about their specific needs, develop more suitable therapeutic tools, and gain suitability and expertise to their practice. At the same time, the continuity of the same providers within health care teams favors interdisciplinary integration.

This study also shows that there is a high level of unawareness (50\% or higher) regarding nonconventional and alternative therapies among psychosocial care providers.

A prior study conducted at Hospital de Pediatría Garrahan ${ }^{8}$ showed that $34 \%$ of cancer patients from that hospital used alternative and complementary therapy together with their allopathic medications. This points out the magnitude of the phenomenon and the importance of the fact that treating physicians should have information on this type of practices so that they may be discussed during medical visits, thus promoting a more honest doctorpatient communication, and preventing the use of harmful alternative therapies.

The standards that were more commonly observed were continuation of education and care of healthy siblings. The SIOP recommendations likely require different effort levels for their implementation. For example, information in pediatrics is a controversial topic: it requires establishing agreements between physicians and parents, defining contents to be discussed, communicating with patients with varying levels of understanding, and also a major emotional distress experienced by health care providers when giving bad news. ${ }^{9}$ Favoring school continuation and asking about the wellbeing of healthy siblings are uncontroversial recommendations supported by health care providers, parents, and patients. ${ }^{10}$ Argentina offers access to hospital schools and/or homeschooling programs in every territory. Lastly, sibling care was explored by means of only one question whereas the other topics were analyzed in more depth.

Less than $50 \%$ of providers from the Departments of Mental Health and Social Services have a place where they can share their opinions and doubts; also, hematologists-oncologists perceive a more negative work environment. This is relevant information because a negative view of the work environment is associated with discomfort and physical and emotional symptoms among health care providers, known as "burnout syndrome."

This study considered the SIOP recommendations as the pattern for psychosocial care. ${ }^{3}$ New standards were developed and published later by a different international group. ${ }^{4}$ Although both documents discuss mostly the same topics, the second group considers three topics not included in the SIOP recommendations, which were therefore not explored in this study. Those are intra- and post-treatment neuropsychological monitoring, measures to encourage peer interactions, and the implementation of resources targeted at improving procedure coping mechanisms. Future studies may dwell on these aspects.

One of the limitations of this study is that $37 \%$ of potential informants failed to complete the questionnaire and, more specifically, $47 \%$ of psychosocial care providers did not provide their answers. In addition to undermining the representation of results, such lack of answers may bias the sample in favor of those health care providers who have a special interest in the psychosocial care of patients with blood diseases and cancer and actually took the time to provide the information. Thus, the results of this study may reflect a major interest in the psychosocial care of patients with blood diseases and cancer than what is really provided at all studied hospitals.

Given that this is an observational, descriptive study, results reflect the opinions of health care providers but these were not compared to objective data about the actual situation experienced in the participating hospitals. Also, the instrument used for this investigation hinders the possibility of establishing the meaning given by the different actors to their actions, which may be the topic of future research.

The level of participation in the study was 
lower than expected. However, the study provides baseline data on this subject. These data are also the result of the joint effort of psychosocial care providers from different regions of Argentina. This is uncommon: psychosocial care providers working in oncology usually work alone and tend to come into contact with colleagues in academic settings rather than at work. Widening and strengthening bonds among psychosocial care providers and other health care providers at an intra- and inter-institutional level is now a closer goal thanks to this study.

In order to provide comprehensive care, psychosocial care should be a goal shared by all those involved, regardless of their profession. ${ }^{11}$

As a result of this study, a new challenge is proposed: promoting places for interdisciplinary exchange and production on the base of the SIOP recommendations.

Reaching future interdisciplinary consensus and establishing care protocols to meet the different psychosocial needs of patients seen in Argentina are still pending issues. This type of consensus warrants the access of all patients to a high-quality standard of care and facilitates the work of health care providers by guiding their practice.

\section{CONCLUSIONS}

The study reports partial compliance with the psychosocial care standards recommended by the SIOP at the public hospitals of Argentina.

\section{Acknowledgments}

We would like to thank W. Cacciavillano, M.D., for his valuable and generous collaboration.

\section{REFERENCES}

1. Schvartzman E. Estrategias pasadas, presentes y futuras en oncología pediátrica. Med Infant 2007;16(2):84-6.

2. Moreno F, Dussel V, Abriata G, Orellana L. Registro Oncopediátrico Hospitalario Argentino. Incidencia 20002009, Supervivencia 2000-2007, Tendencia de mortalidad 1997-2010. Buenos Aires: Instituto Nacional del Cancer, 2012.

3. Fann J, Ell K, y Sharpe M. Integrating Psychosocial Care into Cancer Services. J Clin Oncol 2012;30(11):1178-86.

4. Comité de Aspectos Psicosociales de la Sociedad Internacional de Oncología Pediátrica. Recomendaciones sobreaspectos psicosociales deoncología pediátrica. Buenos Aires: Fundación Natali Dafne Flexer, 2006.

5. Wiener L, Kazak A, Noll R, Patenaude A, et al. Standards for the psychosocial care for children with cancer and their families: an introduction to the special issue. Pediatr Blood Cancer 2015;62(Suppl 5):S419-24.

6. Newburger P (Ed). Standards for Psychosocial Care for Children With Cancer and Their Families. Pediatr Blood Cancer 2015;62(Suppl 5):S419-S895.

7. Jacobsen PB, Wagner LI. A New Quality Standard: The Integration of Psychosocial Care Into Routine Cancer Care. J Clin Oncol 2012;30(11):1154-9.

8. Kusznieryk A, Quintana S, Barzotti D. Medicina Complementaria o Alternativa. Estudio exploratorio sobre las prácticas, creencias y actitudes de los familiares de pacientes pediátricos con enfermedades oncológicas. Med Infant 2010;17(4):369-76.

9. Vidaly Benito MC. ¿Qué y cómo se comunica? In La relación médico paciente. Buenos Aires: Lugar; 2010.P.121-8.

10. Thompson AL, Christiansen HL, Elam M, Hoag J, et al. Academic Continuity and School Reentry Support as a Standard of Care in Pediatric Oncology. Pediatr Blood Cancer 2015;62(Suppl 5):S805-17.

11. Carlson LE, Waller A, Mitchell AJ. Screening for Distress and Unmet Needs in Patients With Cancer: Review and Recommendations. J Clin Oncol 2012;30(11):1160-77. 


\begin{abstract}
ANNEX
To whom it may concern,

Based on what we described to you a few weeks ago on the telephone, we are now contacting you with the link to the website where you may complete the Survey on psychosocial care provided to children and adolescents undergoing treatment for blood diseases and cancer.

Please, remember that this is an information survey and its objective is to establish the current situation in each province so that health care standards may be further developed and implemented.

All answers will be confidential. The survey is very simple and should only take about 10 minutes or less of your time.

The software will automatically save your answers. For this reason, if you start taking the survey and have to stop, you may continue completing it by clicking on the link again. Please remember that answers are saved by page. This means that if you did not complete all questions on the same page, answers will not be saved and you will have to answer those questions again. Once the study is completed, we will share results and invite you to take part and make suggestions regarding the standards. Also, we would like you to know that in August, the Argentine Society of Pediatric Hematology and Oncology (Sociedad Argentina de Hematooncología Pediátrica, $S A H O P$ ) will hold a congress in the Autonomous City of Buenos Aires, and the preliminary results will be presented there.

We look forward to your participation. If you have any questions or suggestions please contact..........
\end{abstract}

TO COMPLETE THE SURVEY, CLICK HERE .........

Argentine Society of Pediatric Hematology and Oncology Committee on Psychosocial Issues

Dear Colleague,

The Argentine Society of Pediatric Hematology and Oncology (Sociedad Argentina de Hematooncología Pediátrica, SAHOP) was founded in 2011. Its objectives include researching and developing cooperative actions among health care providers and organizations devoted to looking after children and adolescents with cancer. The Psychosocial Area has been functioning as part of the SAHOP since 2012.

We would like to know the status of care received by children and adolescents under treatment for blood diseases and cancer in relation to psychosocial aspects to subsequently develop health care standards by consensus. The information provided by you will be confidential and used exclusively within the scope of this survey.

Please find attached the survey that will help us assess the situation in each hospital. Answers should reflect the opinion of your department staff working with patients with blood diseases and cancer. The survey should only take about 10 minutes or less of your time, and the information provided will be very valuable in the pathway towards our goal.

Thank you very much for your help.

Psychosocial Area - SAHOP

\title{
Survey on psychosocial care provided in relation to pediatric oncology
}

Please, mark with an " $X$ " the answer that you consider most representative of the situation at your department.

Personal data

Hospital where you work:

City and province:

Hospital telephone number:

E-mail address:

Department where you work:

Degree and specialty:

How many health care providers are part of your department?

How many members of your department's staff provide care to patients with blood diseases and cancer?

Are these health care providers exclusively dedicated to patients with blood diseases and cancer?

Do you think the human resources available at your department to work in the hematology and oncology area are sufficient?

Are the human resources working in the hematology and oncology area contract employees?

If they are contract providers, who pays for their services?

How many new patients with blood diseases and cancer are seen at your department every year?

E-mail addresses of health care providers from your department (only in relation to the psychosocial area: hospital's Department of Social Services and Department of Mental Health, foundations and parents organizations outside the hospital): 
Please, mark with an " $X$ " the most adequate answer.

\begin{tabular}{|c|c|c|c|c|c|c|c|}
\hline & $\begin{array}{l}\text { 1: Never, not at all, almost never. } \\
\text { 2: Sometimes, occasionally. } \\
\text { 3: Often, frequently. } \\
\text { 4: Always, almost always. } \\
\text { DK/DA: Does not know, does not answer. }\end{array}$ & 1 & 2 & 3 & 4 & DK/ & Remarks \\
\hline \multirow{6}{*}{$\begin{array}{l}\text { Communication } \\
\text { and } \\
\text { information }\end{array}$} & $\begin{array}{l}\text { At your department, do health care providers provide } \\
\text { diagnosis information to the patient's mother / father? }\end{array}$ & & & & & & \\
\hline & $\begin{array}{l}\text { At your department, do health care providers provide } \\
\text { diagnosis information to the patient? }\end{array}$ & & & & & & \\
\hline & $\begin{array}{l}\text { Is there an agreement (formal or informal) among hematologists- } \\
\text { oncologists, social workers, and providers from the Department } \\
\text { of Mental Health on how to provide diagnosis information? }\end{array}$ & & & & & & \\
\hline & $\begin{array}{l}\text { At your department, do health care providers renew the } \\
\text { information on the course of the disease or any changes } \\
\text { in planned treatment? }\end{array}$ & & & & & & \\
\hline & $\begin{array}{l}\text { At your department, do health care providers encourage intra- } \\
\text { family communication about these topics (e.g., advising parents } \\
\text { that it is not convenient to withhold information from the child)? }\end{array}$ & & & & & & \\
\hline & $\begin{array}{l}\text { Do health care providers from the social area (or Department } \\
\text { of Social Services) provide information about inter-institutional } \\
\text { networks that facilitate treatment access (medications, transfers, } \\
\text { accommodation, disability pension/certificate, etc.)? }\end{array}$ & & & & & & \\
\hline \multirow[t]{3}{*}{ Therapeutic alliance } & $\begin{array}{l}\text { At your department, do health care providers encourage patients } \\
\text { and their family to become involved in treatment (e.g., encouraging } \\
\text { them to ask questions and participate in decision-making)? }\end{array}$ & & & & & & \\
\hline & $\begin{array}{l}\text { Do you work with institutions outside the hospital (e.g., } \\
\text { foundations or parents organizations)? How is help coordinated? }\end{array}$ & & & & & & \\
\hline & $\begin{array}{l}\text { At your department, do health care providers encourage patients to } \\
\text { share with other families (activities conducted inside the hospital, } \\
\text { parents associations, foundations, etc.)? }\end{array}$ & & & & & & \\
\hline $\begin{array}{l}\text { Informed consent } \\
\text { and decision-making }\end{array}$ & $\begin{array}{l}\text { At your hospital, do you request patients' and families' agreement } \\
\text { with a specific treatment with sufficient information and time } \\
\text { as to allow them to make a thoughtful and conscious decision? }\end{array}$ & & & & & & \\
\hline \multirow{2}{*}{$\begin{array}{l}\text { Rejection, } \\
\text { noncompliance, } \\
\text { and treatment } \\
\text { withdrawal }\end{array}$} & $\begin{array}{l}\text { At your hospital, is there a formal mechanism in place to detect } \\
\text { treatment withdrawal or noncompliance in an early manner? }\end{array}$ & & & & & & \\
\hline & $\begin{array}{l}\text { At your department, do you act in a systematic manner in the } \\
\text { case of treatment withdrawal or negligent care? }\end{array}$ & & & & & & \\
\hline \multirow[t]{4}{*}{ Education } & Is there a hospital school? & & & & & & \\
\hline & Does the provincial government offer homeschooling programs? & & & & & & \\
\hline & $\begin{array}{l}\text { At your department, do health care providers take action } \\
\text { to discuss education with parents? }\end{array}$ & & & & & & \\
\hline & $\begin{array}{l}\text { At your department, do health care providers contact the school } \\
\text { if they deem it convenient or necessary? }\end{array}$ & & & & & & \\
\hline Sibling care & $\begin{array}{l}\text { At your department, do health care providers ask about the } \\
\text { emotional health of the patient's siblings in a systematic manner } \\
\text { or do they make recommendations to parents } \\
\text { regarding sibling care? }\end{array}$ & & & & & & \\
\hline \multirow[t]{2}{*}{$\begin{array}{l}\text { Nonconventional } \\
\text { therapies }\end{array}$} & $\begin{array}{l}\text { At your department, do health care providers know the differences } \\
\text { between complementary therapies and alternative therapies? }\end{array}$ & & & & & & \\
\hline & $\begin{array}{l}\text { At your department, do health care providers discuss available } \\
\text { nonconventional therapies with the patients and their parents? }\end{array}$ & & & & & & \\
\hline Survivors & $\begin{array}{l}\text { At your department, do health care providers } \\
\text { provide a planned or systematic follow-up } \\
\text { to survivors of pediatric cancer? }\end{array}$ & & & & & & \\
\hline
\end{tabular}


Terminally ill
patients

Burnout

Availability of
psychosocial
staff members

Recommendations made by the International Society of Pediatric Oncology (SIOP)

\begin{tabular}{|c|c|c|c|}
\hline At your hospital, are there specialists in palliative care? & & & \\
\hline $\begin{array}{l}\text { If there are palliative care specialists, are they requested } \\
\text { to see patients during treatment (e.g., for symptom management)? }\end{array}$ & & & \\
\hline $\begin{array}{l}\text { At your department, do health care providers take into account } \\
\text { the risk of therapeutic obstinacy when they have to decide } \\
\text { whether or not to continue with curative treatment? }\end{array}$ & & & \\
\hline $\begin{array}{l}\text { Is the decision to continue with curative treatment or discontinue } \\
\text { it and shift to palliative care made by health care providers in } \\
\text { consensus (e.g., discussions among different specialists)? }\end{array}$ & & & \\
\hline $\begin{array}{l}\text { Is the decision to continue with curative treatment or discontinue } \\
\text { it and shift to palliative care made together } \\
\text { with the patient's family? }\end{array}$ & & & \\
\hline $\begin{array}{l}\text { Is the decision to continue with curative treatment or discontinue } \\
\text { it and shift to palliative care made together with the patient? }\end{array}$ & & & \\
\hline $\begin{array}{l}\text { At your department, do health care providers offer further } \\
\text { visits for bereaved families? }\end{array}$ & & & \\
\hline $\begin{array}{l}\text { At your department, do health care providers have formal } \\
\text { and informal "safe" places where they can share } \\
\text { their opinions and doubts? }\end{array}$ & & & \\
\hline $\begin{array}{l}\text { At your department, do health care providers have formal } \\
\text { and informal places where they can reflect on the negative } \\
\text { emotions experienced during work? }\end{array}$ & & & \\
\hline $\begin{array}{l}\text { At your department, do health care providers work in an } \\
\text { environment of mutual support, trust, and learning } \\
\text { among colleagues? }\end{array}$ & & & \\
\hline $\begin{array}{l}\text { Do hematologists-oncologists and/or pediatricians request } \\
\text { the participation of members of the Department of Mental Health } \\
\text { to prevent or manage psychiatric or emotional problems? }\end{array}$ & & & \\
\hline $\begin{array}{l}\text { Do hematologists-oncologists and/or pediatricians request the } \\
\text { participation of members of the Department of Social Services } \\
\text { to prevent or manage potential social problems? }\end{array}$ & & & \\
\hline $\begin{array}{l}\text { Does the hospital have psychologists and/or psychiatrists } \\
\text { assigned to care specifically for patients with blood diseases } \\
\text { and cancer? }\end{array}$ & & & \\
\hline $\begin{array}{l}\text { Does the hospital have social workers assigned to care } \\
\text { specifically for patients with blood diseases and cancer? }\end{array}$ & & & \\
\hline $\begin{array}{l}\text { Does the hospital receive support from health care providers } \\
\text { and/or volunteers from aid organizations? }\end{array}$ & & & \\
\hline $\begin{array}{l}\text { May patients and their families seek help at any time from } \\
\text { the Department of Mental Health if they want to? }\end{array}$ & & & \\
\hline $\begin{array}{l}\text { May patients and their families seek help at any time from } \\
\text { the Department of Social Services if they want to? }\end{array}$ & & & \\
\hline $\begin{array}{l}\text { Do you think hematologists-oncologists, pediatricians, providers } \\
\text { from the Department of Mental Health, and social workers work } \\
\text { together as a team (e.g., sharing concerns and clinical strategies)? }\end{array}$ & & & \\
\hline $\begin{array}{l}\text { At your department, do health care providers know the SIOP } \\
\text { recommendations regarding psychosocial care provided to pediatric } \\
\text { patients with blood diseases and cancer? }\end{array}$ & & & \\
\hline $\begin{array}{l}\text { Do health care providers consider the SIOP recommendations } \\
\text { regarding psychosocial care provided to pediatric patients with blo } \\
\text { medical practice? }\end{array}$ & & ses and 0 & cander in their \\
\hline $\begin{array}{l}\text { Do providers from the Department of Mental Health consider } \\
\text { the SIOP recommendations regarding psychosocial care provided } \\
\text { to pediatric patients with blood diseases and cancer in their practice? }\end{array}$ & & & \\
\hline $\begin{array}{l}\text { Do providers from the Department of Social Services consider } \\
\text { the SIOP recommendations regarding psychosocial care provided } \\
\text { to pediatric patients with blood diseases and cancer in their practice? }\end{array}$ & & & \\
\hline $\begin{array}{l}\text { here other providers from the psychosocial area } \\
\text { gists, music therapists, occupational therapists, etc.)? }\end{array}$ & $\mathrm{NO}$ & YES & \\
\hline al on psychosocial care available that may be handed out to patients? & $\mathrm{NO}$ & YES & \\
\hline
\end{tabular}

At your hospital, are there other providers from the psychosocial area (educational psychologists, music therapists, occupational therapists, etc.)?

Is there printed material on psychosocial care available that may be handed out to patients?

Would you like to make a comment? 